\title{
Project of a Pilot-Microgrid connected to the Main Grid
}

\author{
Danilo P. e Silva ${ }^{1 *}$, Daniel Carletti ${ }^{1}$,Tiago M. de Christo ${ }^{1}$, \\ Renan C. Basoni ${ }^{1}$, Macello D. Queiroz ${ }^{1}$, Igor O. Barbosa ${ }^{1}$, \\ Marcos T. D. Orlando ${ }^{2}$, Jussara F. Fardin ${ }^{1}$ \\ ${ }^{1}$ Power Eletronics and Electric Drive Laboratory \\ Federal University of Espírito Santo, Vitória, ES, Brazil \\ ${ }^{2}$ Physics Department, Federal University of Espírito Santo, Vitória, ES, Brazil \\ *danilo.p.silva@aluno.ufes.br
}

\begin{abstract}
The interest on renewable sources of energy and sustainable energy management has driven a lot of countries to develop projects and researches about this subject. The microgrid is one of the approaches within the concept of Smart Grids that has been studied through recent years. This paper describes the recent state of the researches about microgrids in Federal University of Espirito Santo, and presents the pilot project of a microgrid developed in this university. The microgrid is connected to the electrical main grid with wind and solar photovoltaic resources and with a control system for studies on energy management, electrical systems protection, multi-objective optimization and virtual synchronous generation
\end{abstract}

\section{Introduction}

Microgrids, characterized by off-grid systems, have existed for decades to supply remote regions, which do not have conventional electrical distribution grid. To meet sustainable development, technologies based on wind energy, solar energy, biomass and fuel cell have become priority in microgrid integration, driving several countries to adopt policies to encourage the use of renewable energy such as tariff allowance, green/sustainable certificates, credit for investments and govern- mental programs.

In European Union in 2014, renewable energy generation corresponded to $25,5 \%$ of the total energy generated [1]. From this percentage, about $18 \%$ of the renewable energy generated corresponded to solar photovoltaic and wind energy.

In Brazil, Normative Resolution 482/2015 from the Electrical Energy National Agency (ANEEL), which regulates distributed mini and micro-generation, is a great incentive to electric power generation from renewable sources. This reso- 
lution created the Electrical Energy Compensation System, allowing consumers to install small generators in his unit (such as photovoltaic panels, wind microturbines, and others) and exchange energy with the power distribution company in order to reduce the value of his electric bill [2].

In this context, the concept of microgrids arises [3], [4] which is an aggregation of loads and renewable and non-renewable micro-generations operating like an off-grid system or grid-tie controlled system, locally providing power and heat. For the electrical power system, the microgrid can be seen as a single cell and can be considered as a variable single load, or as a variable electrical energy source. Microgrids manages and supply energy for houses, industrial park, shopping centers, commercial buildings, etc. For internal consumers, a microgrid brings great benefits, such as reduction of transmission costs and losses, energy supply reliability, power reserve, decrease in peak demand, and others.

This article was structured and presented next: Section 2 describes the research projects about microgrids of the Electrical Engineering Department of Federal University of Espírito Santo (UFES). The description of the microgrid pilot project is discussed in section 3 , in section 4 the conclusions with further steps for the research and in section 5 the acknowledgements.

\section{Microgrid researches at UFES}

Universities have been strengthening their microgrids and Smart Grid research groups Smart Grid [5] equipping laboratories, purchasing or developing software and building pilot projects for tests and performance analysis. Federal University of Santa Catarina (UFSC) in partnership with Tractebel Energia have an intelligent microgrid laboratory and is developing a hybrid microgrid AC/DC with solar photovoltaic generation, wind generation and energy storage [6]. The Center of Studies in Regulation and Energy Quality (ENERQ) of the University of São Paulo (USP) develops researches about Smart Grids, distributed generation and microgeneration. Federal University of Espírito Santo (UFES) also proposed to participate with investigations the new reality of the energy system, collaborating with results, analysis and human resources formation.

The beginning of the investigation resulted in a doctorate, which was concluded in 2010 [7] and one of its contributions was an irradiance and temperature measurement estimator for a photovoltaic system. The continuity of the research evaluates the impact of distributed generation in decision-making processes of technical planning of the electrical energy distribution company [8] and the project and development of a microgrid, including the concept of Smart Grid, for the Brazilian Station in Antarctica [9]. In his master's degree [10] Azini developed a software for non-intrusive monitoring of residential loads, which will be included in the pilot project. The application of a virtual synchronous generator to control inverters in distributed generation is also one search object [11].

\section{Pilot Project}

The Microgrid pilot Project was motivated on recent interest of the scientific community of UFES. Real data collection 


\section{Blucher Proceedings VIII Encontro Científico de Física Aplicada Blucher}

and the possibility of implementation of management of a real microgrid are fundamental elements for the continuity of this research line. One of the main objectives of microgrid management is energy cost reduction along with reduction of environmental impacts caused by the production and transmission of electric energy through conventional grids.

The pilot project will be connected to the conventional grid, owning wind and solar photovoltaic sources and controllable loads managed by a Supervisory, Control and Data Acquisition System (SCADA). Figure 1 shows the schematic diagram of the pilot microgrid.

The connection point is the place where the microgrid gets connected to UFES' grid, which is tied to the power distribution company. The point of common coupling (PCC) is an electrical panel which function is to interconnect power sources, loads and other equipment to the microgrid in a common bus and making each one's electrical protection. PCC has voltage and current sensors for data acquisition through SCADA.

Solar photovoltaic generation if composed of $6 \mathrm{PV}$ panels of $250 \mathrm{Wp}$ each, model AC-250P/156-60S of Axitec, one frequency inverter of $2,0 \mathrm{~kW}$, output voltage of $220 \mathrm{~V}$, model Fronius Galvo 1.1-5 and on AC protection panel. The inverter has the function of anti-islanding protection, not allowing the PV generation to operate in the off-grid mode. Figure 2 shows the PV modules installed.

The wind generator is composed of the wind turbine with diameter of $2,46 \mathrm{~m}$, power of $1,0 \mathrm{~kW}$, output voltage of 220 Volts model GERAR246 of Enersud. In the set of wind generator, there is the frequency inverter with power of $1,5 \mathrm{~kW}$, voltage of $220 \mathrm{~V}$, model Ningbo Ginlong Technologies CO.LTD GCI-1.5kW, the damping resistor to dissipate the excess energy of the inverter and the controller that protects the wind system and interconnects all the equipment. The inverter has the function of anti-islanding protection, not allowing the wind generation to operate in the off-grid mode. Figure 3 shows the wind generator installed.

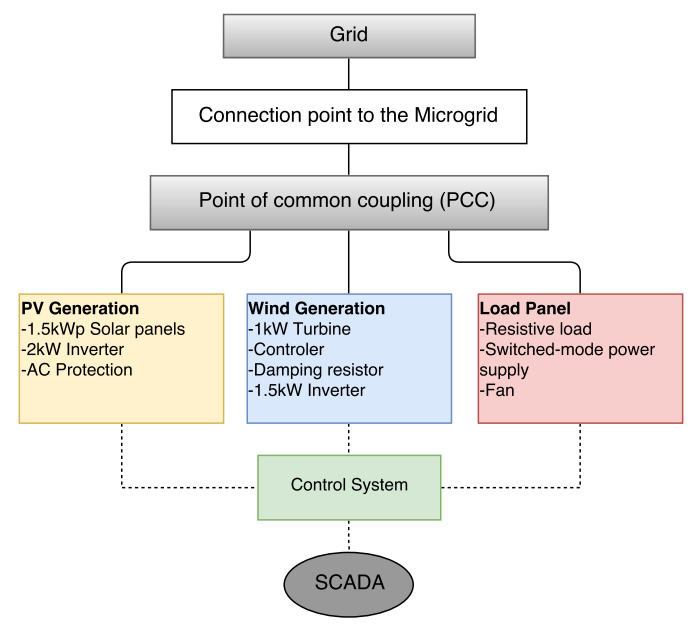

Figure 1: Schematic diagram of the pilot project

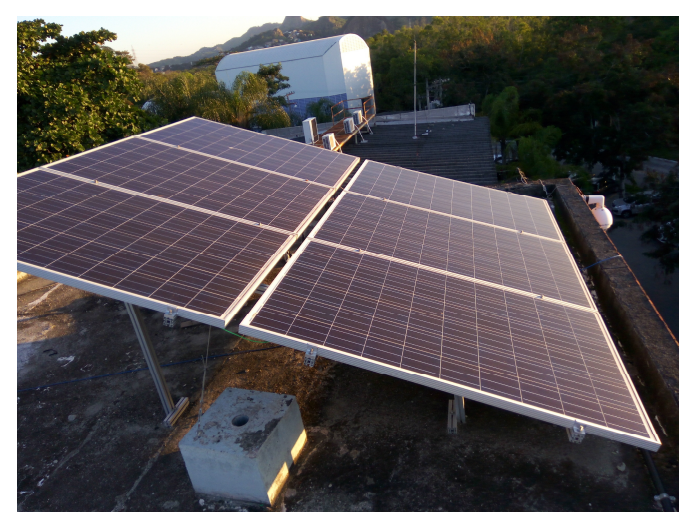

Figure 2: Six photovoltaic models installed of $1,5 \mathrm{kWp}$

The load panel feeds six resistors of $500 \mathrm{~W}$ each, a switched-mode power supply of $400 \mathrm{~W}$ and a fan of $100 \mathrm{~W}$. Besides the function of protection, this panel has contactors, push-buttons and flags so that 


\section{Blucher Proceedings VIII Encontro Científico de Física Aplicada Blucher}

the loads are turned on independently, guaranteeing flexibility to the simulations of demand profiles.

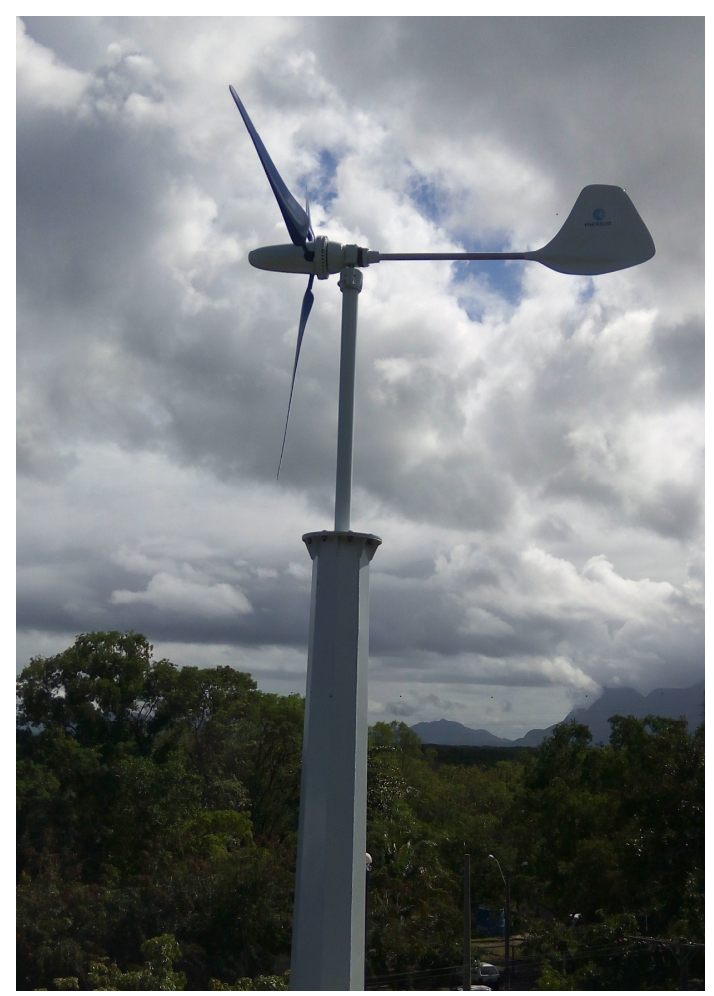

Figure 3: $1 \mathrm{~kW}$ Wind Generator

The pilot project is in assembly and test stage. The PV and wind generations are installed, as well as the resistive loads and the PCC and loads panels.

The figures 4 and 5 represents the energy generation of the photovoltaic and wind sources for one day, respectively. The solar generation starts at 5:45 AM, the peak generation reach $1200 \mathrm{~W}$ at 11:45 AM and the generation finishes after 5:15 PM. The wind power generated is small because the wind speed was low on this day. The maximum value of day is $500 \mathrm{~W}$ at 8:00 PM. These data were obtained through of data acquisition system of the solar and wind inverters.

Some equipment will be installed in the future: the inverter emulator of distributed generation, the control system with SCADA and the battery bank with load controller.

The operating principle of the pilot project is based on allowing the operation of the wind and solar generation for as long as possible. The data of voltage and current will also be collected to monitor other electrical quantities (power in $\mathrm{kW}$, power factor, etc.) the loads will be discretely controlled by a SCADA system control with interlock and sequencing logics. Simulating different demand profiles and evaluating the performance of wild and solar generators will be possible. The user will be able to create his own demand profile according to his research. Advanced resources will be added to the microgrid management such as demand prediction, usage of superconductors to limit short circuit currents (SFCL) and the renewable energy offer. Algorithms for load escalation and battery recharging optimization, as well as optimization of costs of the energy consumed from the main grid will be evaluated. It is highlighted that there are data on wind and solar incidence being collected by a weather station in the location where the wind generator and PV panels are installed.

The microgrid uses conventional protection based on low voltage circuit breakers. The circuit breakers have long time response on overcurrent, because besides the stage of fault detection, time for mechanical opening of the circuit breaker is necessary. Considering an investigative proposal, this micro-network provides the laboratory environment necessary to investigate a new protection device against faults associated with short-circuits, the resistive superconductor current limiter. The use of the fault current limiting superconductor (SFCL) has the ability to interrupt fault currents immediately after the SFCL overcurrent limit is exceeded [12], 


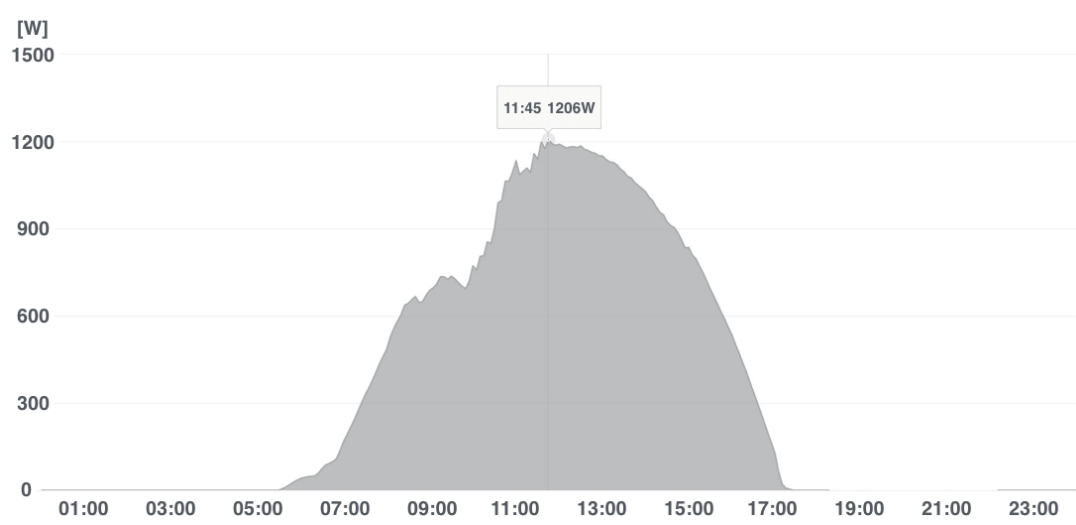

Figure 4: Photovoltaic generation for one day

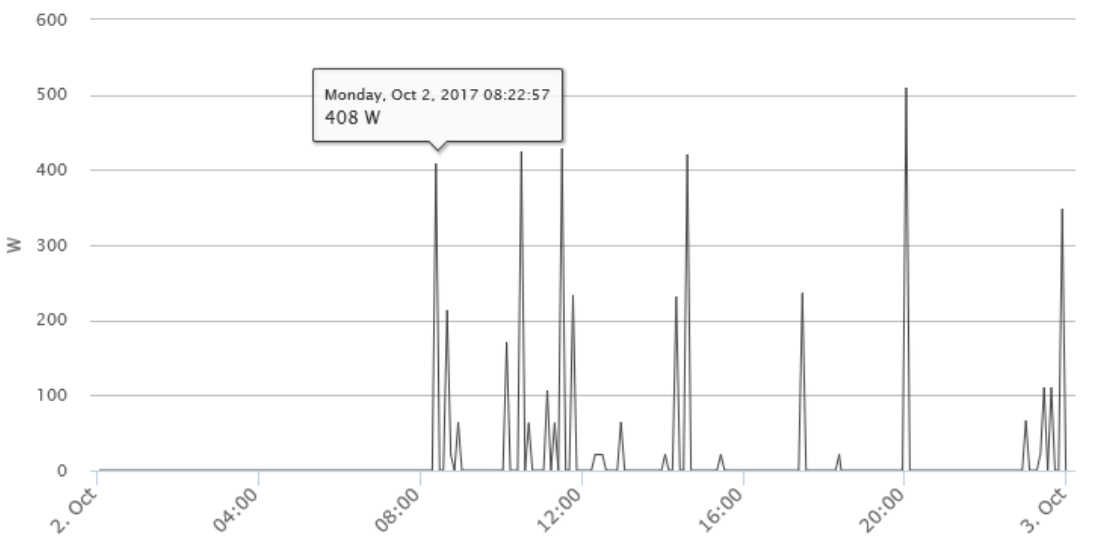

Figure 5: Wind generation for one day

[13].

\section{Conclusions}

The development in research on the microgird management shows a necessity of confronting simulated models with real values. The pilot project meets this trend, opening up a variety of options for research at UFES. Future work and research will address the virtual emulation of energy sources through dSPACE modules, the development of frequency converters that allow the microgrid to operate in isolated mode, including batteries and load controller for multi-objective optimization studies, data collection of irradiance and direction of the wind for model iden- tification, simulation of the electrical protection through searches with current limiting superconductors.

\section{Acknowledgments}

The authors thank a Foundation for Research and Innovation Support of Espírito Santo (FAPES) project number 67666027 for financial support.

\section{References}

[1] European Comission, statistical office of the European Union (Eurostat). Avaliable: http://ec.europa.eu/eurostat/statistics- 
explained/pdfscache/1216.pdf, Access on July 7, 2017.

[2] Electrical Energy National Agency - ANEEL, Normative Resolution $\mathrm{N}^{\mathrm{O}}$ 482, Avaliable: http://www2.aneel.gov.br/cedoc/ ren2012482.pdf, Access on July 7, 2017.

[3] Bidram, A.; Davoudi, A. Hierarchical Structure of Microgrids Control System, IEEE Transactions on Smart Grid, vol. 3, no. 4, p. 1963 1976, 2012.

[4] D. E. Olivares; et al., Trends in Microgrid Control,IEEE Transactions on Smart Grid, v. 5, no. 4, p. 19051919,2014.

[5] Anderson, Roger N., et al. Adaptive stochastic control for the smart grid. Proceedings of the IEEE 99.6 (2011): 1098-1115.

[6] Ortman, M. S. , Andreta, A. G., Camurça, L. J. e Silva, V. L. Arquitetura e Componentes de uma Microrrede Inteligente Experimental. VIII Congresso de Inovação Tecnológica em Energia Elétrica (VIII CITENEL), Costa do Sauípe,BA, august 17-19, 2015.

[7] Da Costa, W. T.; Fardin, J. F.; Simonetti, D. S. L.; De V. B. M. Neto, L. . Identification of photovoltaic model parameters by Differential Evolution. In: International Conference on Industrial Technology , 2010, Vi a del Mar. . p. 931910.

[8] Donadel, C. B; Fardin, J. F; Encarnação, L. F. Electrical distribution network operation with a presence of distributed generation units in a Pre Smart Grid environment using a clustering-based methodology. Energy Systems, v. 1, p. 1-23, 2015.

[9] Christo, T. M.; Fardin, J.F.; Simonetti, D. S. L.; Encarnacao, L. F. ; Alvarez, C. E.. Design and analysis of hybrid energy systems: The Brazilian Antarctic Station case. Renewable Energy. v. 88, p. 236-246, 2016.

[10] Fardin, J. F.; Salles, E. O. T. Software for Nonintrusive Monitoring Residential Loads with two Different Approaches. In: WorkInnova: Denmark-South America Workshop on Sustainable Technologies, Research and Innovation., 2012, Vitória. WorkInnova, 2012.

[11] Carletti, D.; Fardin, J. F.; Encarnação, L. F. Desenvolvimento de um Gerador Síncrono Virtual. In: IEEE/IAS INDUSCON, 2014, Juiz de Fora / MG. Anais do IEEE/IAS INDUSCON 2014. v. 1.

[12] Passos, C A C, Bolzan, M S, Orlando, M T D et al, Critical Current Model for Polycrystalline Compounds with an Intrinsic Solid Solution of Two Mixed Superconductor Phases, Journal of Superconductivity and Novel Magnetism, 28 (7), (2015) 1875-1880.

[13] Gannamani, N. K., Jagadesh, G.,Optimal Performance of Superconducting Fault Current Limiter Applied to Micro Grid System, International Journal of Power System Operation and Energy Management, Volume-4, Issue-1, 2013. 